上的弧段 $L_{1}$ 必和正负 $y$ 轴各有一交点. 但曲线 $l$ : $y=x^{2}, x \geqslant 0$, 是方程 (1) 在右半平面上等价方程

$$
\frac{d y}{d x}=\frac{-2 x^{3}}{y-2 x^{2}}
$$

的积分曲线, $l$ 和 $L_{1}$ 必相交, 从而得出矛盾. 故方 程 (1) 无极限环,即知上文的改进不能成立.

葛渭高

(北京工业学院数学教研室)

\title{
闽南沿海“老红砂”的特征与成因
}

自福建省的平潭身至闽县交界的诏安县, 在沿 海的岛屿、半岛及沿岸䖬角地带, 断续分布一种红色 半固结的以砂质为主的沉积物, 习称 “老红砂”. 它 们的主要特征是:

1. 以红色为主. 物质组成多为次圆状的石英粉 细砂, 极少见有中、粗砂及细砾; 2. 剖面结构较单一, 偶见交错层理或水平层理. 垂直节理发育, 常形成 深切沟谷; 3. 一般组成海拔 20 米左右的二级海积阶 地, 阶地面连续平坦, 微向海倾斜; 4. 几乎都发育在 花岗岩低丘环绕的海湾, 上覆于有明显海蚀迹象的 花岗岩风化壳; 5. 厚度和出露高度有时因后期构造 变动或断裂活动的影响和改造而发生显著的变化.

样品的分析鉴定结果表明,老红砂的柆度参数, 近似于海滩砂的特征. 在重矿物组成中, 钛铁矿和 电气石的含量较低, 因而有别于东南沿海大陆架受 陆源物质影响较大的沉积物. 微量元素的含量虽由 于吸附能力小于粘土岩和时代较新而接近于陆相沉
积,但某些元索的含量, 如镓、钾、钩等, 仍相当于海 相沉积. 在已篮定的剖面中, 硅藻类化石和有孔虫、 介形虫化石,都属于滨海相沉积物所有. 据此, 笔者 认为,老红砂沉积具有近源滨海相沉积的特点.

老红砂与闽南广泛出露的一套在滨海沼泽环境 中形成的黑色淤泥层可能为同时异相的产物. 后者 的时代, 根据其中所含有机物质的 ${ }^{24} \mathrm{C}$ 年代测定结 果, 已确定为晚更新世晚期. 另在较多的剖面上,老 红砂被全新世和现代的各类沉积所覆盖, 故其时代 亦可能属于晚更新世的晚期.

对老红砂更多的发现以及多项测试数 据的 取 得, 将有助于对其成因和时代的进一步确定, 也将有 助于查明这类沉积物分布区的海岸变迁, 古地理演 化及其与新构造运动的关系.

\section{张虎男 (广东省地震局，广州)}

\section{苧麻嫩枝扞插繁殖的研 究}

通常用䒯麻地下茎进行无性繁殖, 由于它的䇣 殖系数低，推广良种受到限制. 无其对麻㡈中发生 的个体变异和植株上发生的芽变,难以分离和繁殖. 为此, 我们研究了莹麻嫩枝的扞插繁殖工作, 以便 保存和繁殖已出现的变异部分和加速苧麻的育种工 作.

营麻濑枝的扞插繁殖工作十分容易. 具体方法 是在䒓麻生长季节内切下嫩枝, 一般为长 $6.26 \pm$ 1.83 厘米,粗 $0.30 \pm 0.06$ 厘米,重 $1.10 \pm 0.40$ 克和 叶片数 $4.66 \pm 0.94$ 的切段. 然后, 插人加有生根溶 液的 100 毫开锥形瓶内. $2-3$ 天后, 浸入溶液的嫩 枝表面出现突起, 排列成五行, 接着, 突起逐渐长大
并突破表皮,平均每厘米有 13.2 个突起.一周后,嫩 枝表面发生不定根, 每个嫩枝平均 发生 $12.86 \pm$ 5.76 个不定根, 不定根的长度为 $23.69 \pm 10.30$ 毫 米. 着生在嫩枝基部的不定根为 $8.20 \pm 4.15$, 它相 当于不定根总数的 $63.76 \%$. 所以, 大多数不定根 集中在嫩枝基部。然后将带根的嫩枝及时移入土中 形成小植株.

本工作也对营麻嫩枝的生根过程进行了组织学 研究.

$$
\text { 管 和李人圭 }
$$

(华东师范大学生物学系,上海) 